\title{
Pemberdayaan bagi Masyarakat Mudah dan Bisa Jadi Usaha Rumahan Melalui Pelatihan Pengembangan Wirausaha Cara Ternak Ikan Cupang Di Kelurahan Putat Jaya Surabaya
}

\author{
Empowerment for the Community is Easy and Can Be a Home-Based Business Through \\ Training in Entrepreneurship Development of Betta Fish Farming in Putat Jaya Village, \\ Surabaya
}

J.E. Sutanto*
Tina Melinda
David Sukardi Kodrat
Department of Management,
Universitas Curabaya,
Surabaya, East Java, Indonesia
'email: je.sutanto@ciputra.ac.id
Kata Kunci
Ternak ikan cupang
Demam berdarah Dengue
Pelatihan pengembangan
Pelatihan wirausaha
Pemberdayaan masyarakat
Keywords:
Betta fish cattle
Dengue Hemorrhagic Fever
Development training
Entrepreneurship training
Community development
Published: September 2020

\begin{abstract}
Abstrak
Tujuan dari kegiatan pemberdayaan masyarakat merupakan aksi peduli Tim Pelaksana dari Universitas Ciputra Surabaya terhadap masyarakat untuk memberikan meningkatkan pengetahuan dan melakukan secara mudah dengan langsung praktek. Metode kegiatan pemberdayaan masyarakat ini menggunakan metode: ceramah, diskusi kelompok, pelatihan wirausaha, FGD, praktek menggunakan sarana dan prasarana. Pertama tentang pentingnya memelihara ikan cupang dan cara mudah untuk mencegah terjangkit demam berdarah dengue (DBD), sehingga faktor kesehatan masyarakat menjadi lebih baik, sehingga kemungkinan terjangkitnya DBD sudah relatif kecil sekali. Data secara statistik di Kota Surabaya dipastikan terjadi penurunan penderita penyakit DBD yang signifikan. Kedua, setelah diberikan pelatihan pengembangan wirausaha, maka diharapkan masyarakat secara individu nantinya bisa menjadi peluang usaha rumahan dan sekaligus menjadikannya sebagai upaya pemberdayaan ekonomi warga mengingat beternak ikan cupang bisa mempunyai tambahan pendapatan bagi masyarakat. Ketiga faktor lokasi Kelurahan Putat Jaya adalah sangat strategis, dengan demikian menjadi peluang usaha bagi masyarakat Putat Jaya terutama bagi calon konsumen dari wilayah Surabaya maupun dari luar Surabaya, untuk menjangkau lokasi untuk mendapatkan ikan cupang.
\end{abstract}

\begin{abstract}
The purpose of community empowerment activities is a caring action from the Implementation Team of Ciputra University Surabaya towards the community to increase knowledge and carry out easily with direct practice. These community empowerment activities use lecture methods, group discussions, entrepreneurship training, FGDs, and the practice of operating facilities and infrastructure. First, about the importance of raising betta fish and an easy way to prevent dengue hemorrhagic fever (DHF), so that public health factors become better and the possibility of contracting DHF is relatively slight. Statistical data in the city of Surabaya shows a significant decrease in DHF sufferers. Second, after being given entrepreneurship development training, it is hoped that the community individually can become a home-based business opportunity as well as making it an effort to empower the citizens' economy, bearing in mind that raising betta fish can have additional income for the community. Third, the location factor of Putat Jaya Village is very strategic, so that it becomes a business opportunity for the Putat Jaya community, especially for prospective consumers from inside and outside Surabaya to reach locations to get betta fish more efficiently.
\end{abstract}




\section{PENDAHULUAN}

Barisan et al. (2017) serta Mustanir \& Rusdi (2019) mengemukakan dalam upaya memberdayakan masyarakat ada tiga aspek antara lain menciptakan suasana atau iklim yang memungkinkan potensi masyarakat untuk berkembang dan masyarakat memiliki potensi yang dapat dikembangkan, memperkuat potensi yang dimiliki oleh masyarakat dengan menampung berbagai masukan, menyediakan prasarana dan sasaran yang baik serta akses pada sumber-sumber kemajuan ekonomi seperti modal, teknologi, informasi, lapangan kerja, dan pasar, dan memberdayakan masyarakat dalam arti membantu dan mendampingi kepentingan masyarakat untuk lebih maju dari aspek ekonomi. Mustanir et al. (2019) menyebutkan ada beberapa tahapan-tahapan yang dilakukan dalam pemberdayaan masyarakat. Tahapantahapan yang dilakukan dalam pemberdayaan masyarakat antara lain:

1. Pemeilihan tempat atau lokasi, sebagai area rencana kegiatan pemberdayaan.

2. Pelu mengadakan sosialisasi kepada masyarakat, pejabat setempat dan pihak pelaksana pemberdayaan.

3. Melalui adanya proses pemberdayaan masyarakat yang terdiri dari: perencanaan, pelaksanaan, monitoring dan evaluasi.

4. Kegiatan berupa pendampingan kepada masyarakat.

Pelaksanaan pelatihan mulai dari materi entrepreneurship dan pelatihan pengembangan wirausaha cara ternak ikan cupang. Universitas Ciputra Surabaya, telah mengundang dan sekaligus bekerja sama dengan Master Dani, yaitu khusus pakar dibidang budidaya ternak ikan cupang, kegiatan ini merupakan bukti dari Tim Abdimas, Universitas Ciputra Surabaya atas keperduliannya, dan kepekaannya sebagai dosen terhadap tanggung jawabanya untuk menjalankan tri dharma perguruan tinggi.

Seseorang dapat dikatakan sebagai wirausahawan jika mempunyai kemampuan melihat dan menilai peluang, mengelola sumber daya yang dibutuhkan serta mengambil tindakan yang tepat, guna memastikan sukses secara berkelanjutan (Pio, 2016; Wahyudin, 2012). Wirausahawan adalah orang yang berani membuka kegiatan produktif yang mandiri, dan tidak tergantung pemerintah (Setyawati et al., 2018; Hadiyati, 2011).

Kelurahan Putat Jaya, Surabaya adalah merupakan salah satu kelurahan yang di wilayah Kota Surabaya yang mencapai kasus demam berdarah dengue (DBD) yang paling tinggi, walaupun tren penyakit DBD di Kota Surabaya mengalami penurunan yang siginifikan, dimana Februari 2019 sudah mencapai penurunan 19 kasus. Wali Kota Surabaya Tri Rismaharini tetap meminta kepada semua pihak, terutama Bumantik (Ibu Pemantau Jentik) untuk selalu gencar turun memantau jentik di rumah-rumah warga. Pada kesempatan itu, Wali Kota Risma menjelaskan sebetulnya demam berdarah itu bisa dicegah. terbukti, dari tahun ke tahun kasus penderita demam berdarah menurun di Kota Surabaya. Alternatif pencegahan terhadap penyakit DBD, banyak sekali cara maupun solusinya, namun Universitas Ciputra Surabaya, dalam rangka melakukan kegiatan kepada masyarakt yaitu melalui pelatihan pengembangan wirausaha cara ternak ikan cupang. Tujuan dan maafaat dari pelatihan wirausaha: pertama, pentingnya memelihara ikan cupang dan sekaligus cara mudah untuk mencegah terjangkit DBD. Penyakit DBD itu sendiri disebabkan oleh nyamuk aedes aegypti (Atikasari \& Sulistyorini, 2018). Nyamuk ini sangat gemar untuk bertelur di atas permukaan air yang tergenang dan diam. Salah satu yang cukup sering jadi favorit nyamuk ini bertelur adalah di tempat penampungan air, termasuk bak mandi (Hendri et al., 
2010). Kedua, dengan diberikan pelatihan pengembangan wirausaha bagi masyarakat diharapkan, setelah mengikuti pelatihan tersebut, maka secara individu kegiatan masyarakat nantinya bisa menjadi usaha rumahan dan dalam jangka pendek bisa menjadi usaha sampingan dalam meningkatkan perekonomian masyarakat (Hasmidyani et al., 2017). Pasalnya, pengusaha yang juga mahasiswa Teknik Lingkungan di salah satu kampus di Surabaya ini telah berhasil menembus pasar ekspor. Ia telah berhasil mengekspor ikan-ikan beragam warna tersebut hingga ke Swedia, Meksiko, dan Amerika Serikat. Untuk satu ekor ikan cupang bisa dijual dengan harga 25 USD hingga 50 USD di pasar Internasional. Sedangkan, di pasar lokal, ia menjual satu ekor ikan cupangnya dengan harga Rp 50.000 hingga Rp 350.000. Melemahnya nilai tukar rupiah ternyata tidak selalu berdampak buruk, setidaknya bagi Nanda Panji, pengusaha UMKM Budidaya Ikan Cupang yang berlokasi di Krukah Selatan, Surabaya ini.. Hal ini menunjukkan arti pentingnya memprioritaskan peran UMKM di Indonesia (Alamsyah et al., 2018).

\section{METODE PELAKSANAAN}

Pemberdayaan kepada masyarakat diberikan peluang yang disesuaikan dengan kemampuan yang dimiliki melalui partisipasi aktif dan berkelanjutan dengan memberikan peran yang lebih besar secara bertahap sesuai dengan potensi yang dimiliki, diakomodasi aspirasinya serta diberikan motivasi untuk melakukan self evaluation terhadap pilihan dan hasil pelaksanaan (Nugroho, 2017). Proses Pemberdayaan Masyarakat melalui beberapa tahap, diantaranya Tahap Persiapan yaitu dilakukan persiapan tim, sosialisasi dan penetapan materi pelatih, biaya dan tim pendampingan. Koordinasi yang dilakukan baik dari Universitas Ciputra Surabaya, diharapkan untuk memudahkan dalam persiapan maupun pelaksanaan pelatihan. Selanjutnya Tahap Pengkajian, dimana peserta ditentukan oleh panitia pelaksanan yang berkoordinasi atas pihak Ketua RW dan RT, Kelurahan Putat Jaya. Langkah selanjutnya adalah memfokuskan kegiatan pada masyarakat yang sudah diplih dan sekaligus tertarik untuk melakukan kegiatan pelatihan cara beternak ikan cupang. Tahap Sarana dan Prasarana: rencana terkait pelatihan disampaikan seperti terkait waktu pelatihan, sarana dan prasarana pelatihan serta rencana untuk mengembangkan usaha mereka. Tahap Pelaksanaan Pelatihan: tahapan langkah kegiatan antara lain, kegiatan pelaksanaan pelatihan, jumlah peserta pelatihan dan pendampingan serta narasumber.

Pelatihan tersebut dilaksanakan di Balai Kelurahan Putat Jaya. Tahapan ini merupakan salah satu tahapan yang paling penting dalam program pemberdayaan dimana perencanaan yang dilakukan sudah sesuai dengan pelaksanaan program atau kegiatan. Semua pihak yang bertugas terlibat dalam pelaksanaan dan salah satu prinsip pemberdayaan yakni adanya kolaborasi proses antara masyarakat yang diberdayakan dengan baik dari Universitas Ciputra Surabaya dan Kelurahan yang diwakili oleh Tim Pokja, Tim Puskesmas dan Tim Jumantik yang memberdayakan. Kegiatan pelatihan dilaksanakan di Kantor Kelurahan Putat Jaya, Kecamatan Sawahan, Surabaya. Dipilihnya lokasi ini karena daerah terdampak merupakan cakupan wilayah Kelurahan Putat Jaya (Orta et al., 2016). Hal tersebut dimulai sejak Dolly van De Mart mempekerjakan beberapa gadis untuk melayani para tentara belanda hingga akhirnya tersebar luas informasinya di kawasan Putat Jaya (Oktaviari \& Handoyo, 2017). Dokumentasi sambutan oleh Perwakilan LPPM Universitas Ciputra Surabaya dan Lurah Putat Jaya disajikan pada Gambar 1 dan 2 . 


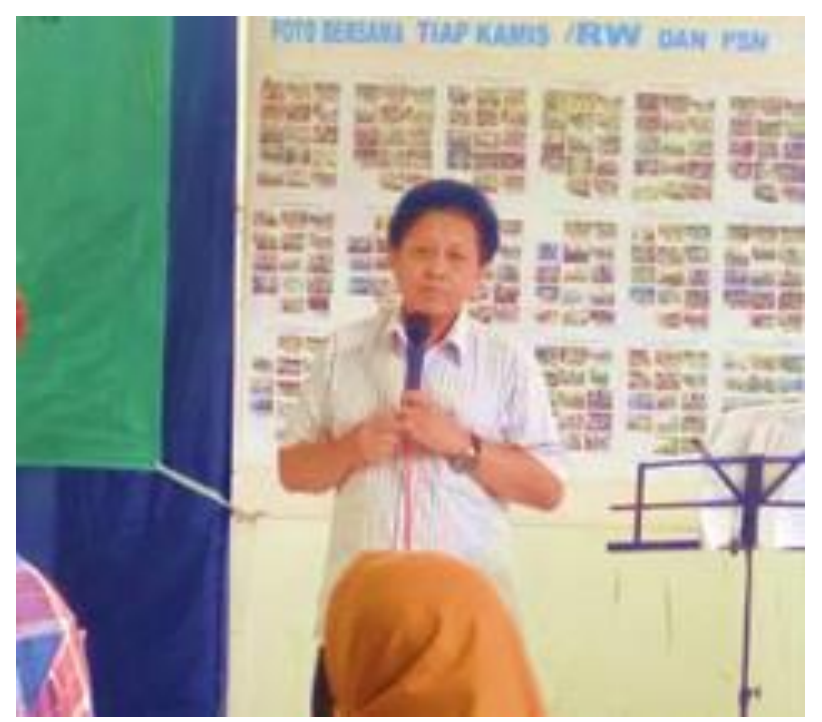

Gambar 1. Sambutan dari LPPM Universitas Ciputra Surabaya

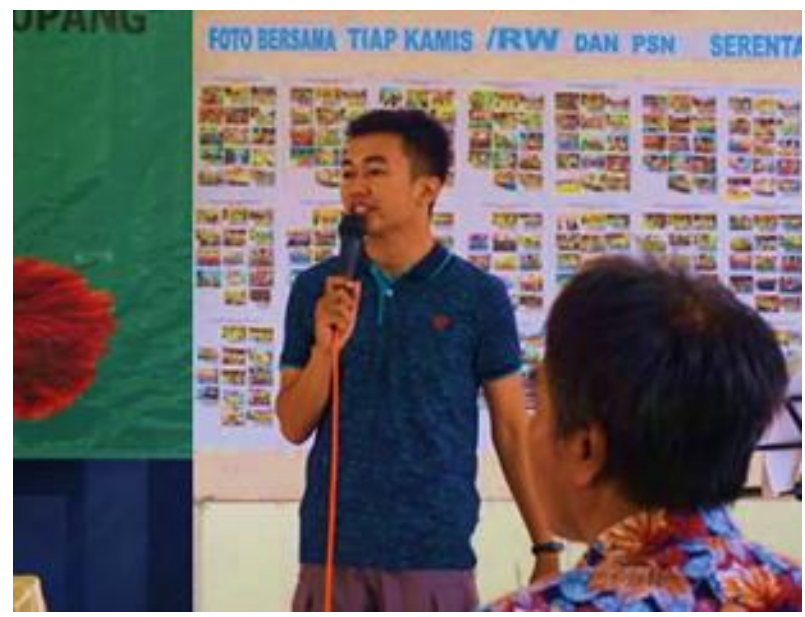

Gambar 2. Sambutan dari Lurah Putat Jaya Bapak Bryan Ibnu Maskuwaih, S.STP.

\section{HASIL DAN PEMBAHASAN}

Selama program pelaksanaan kegiatan pelatihan dua hari mulai tanggal 12-13 Januari 2020 telah diikuti dengan total 45 peserta. Peserta pelatihan mulai dari RW 01 sampai dengan RW 15, dan masing-masing perwakilan RW diwakili 3 orang peserta, dan salah satu Ketua Kelompok telah menerima bantuan indukan ikan cupang yang diserahkan oleh Sekretaris Kelurahan seperti ditunjukkan pada Gambar 3.

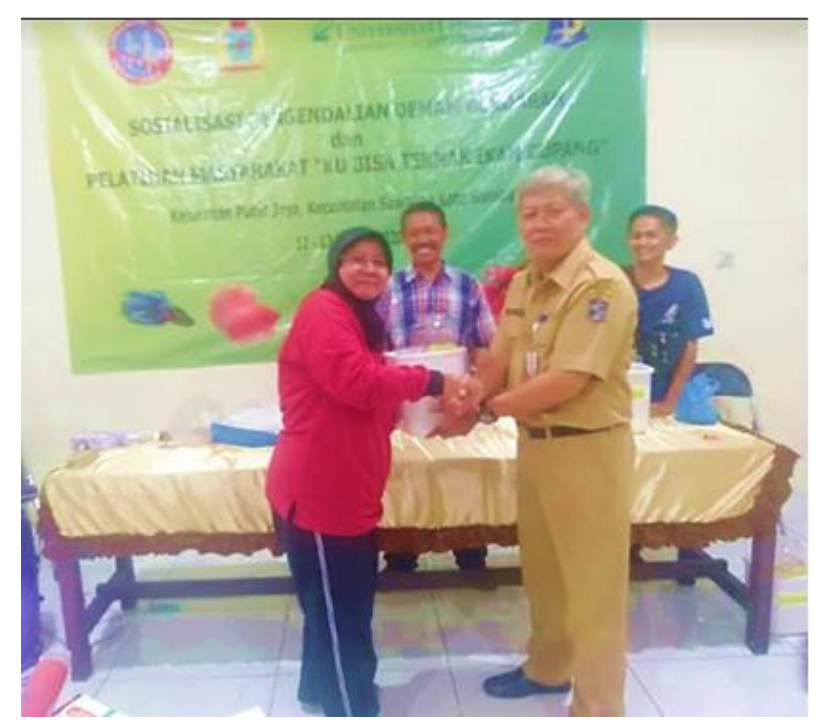

Gambar 3. Perwakilan salah satu Ketua Kelompok menerima Indukan dari Sekretaris Kelurahan Putat Jaya

Diskusi antar kelompok seperti Gambar 4, merupakan model yang dilakukan dalam pelaksanaan pelatihan yang diberikan ini dengan tujuan agar masing-masing kelompok memberikan pertanyan atau maupun studi kasus, sehingga diharapkan peserta akan banyak memahami persoalan yang dihadapi. Hasil diskusi tersebut akan di sampaikan kepada narasumber yaitu Master Dani, untuk menjadi diskusi bersama semua kelompok semacam FGD pada umumnya.

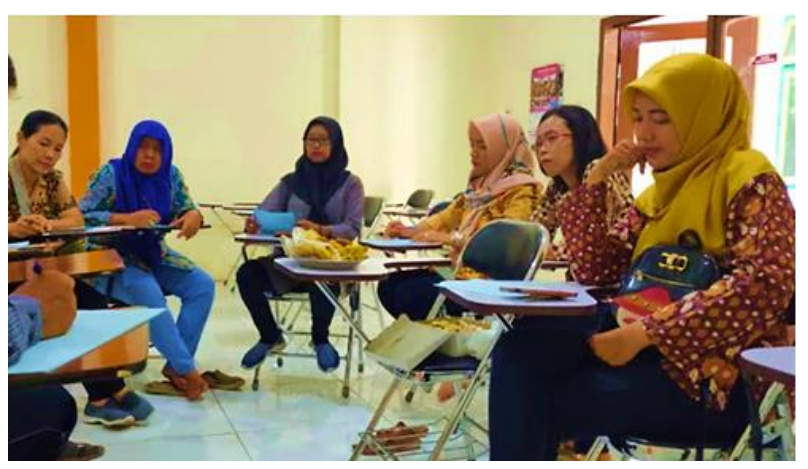

Gambar 4. Diskusi antar Kelompok

Setelah ishoma, masing-masing kelompok kembali ke ruuang pelatihan, dan sekaligus melakukan FGD, bersama Narasumber Master Dani, sehingga banyaknya persoalan atau kasus yang kurang jelas akan dapat 
dijawab langsung oleh narasumber, sebagaimana disajikan pada Gambar 5.

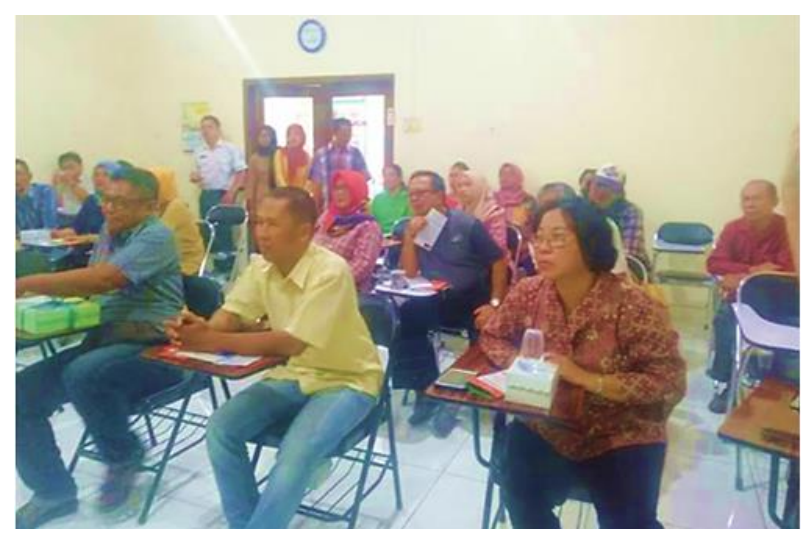

Gambar 5. Diskusi Bersama dengan Narasunber Master Dani

Gambar 6 menunjukkan beberapa macam hadiah, diberikan kepada kelompok yang terbaik, hadiah tersebut telah disiapkan dan sekaligus merupakan partisipasi dari pihak Puskemas Kelurahan Putat Jaya, melalui pembawa acara yaitu Ibu Maya Santyawati, yang sangat bersemangat untuk melontarkan beberapa pertanyaan-pertanyaan kepada peserta dari masing kelompok RW 01 sampai dengan RW 15.

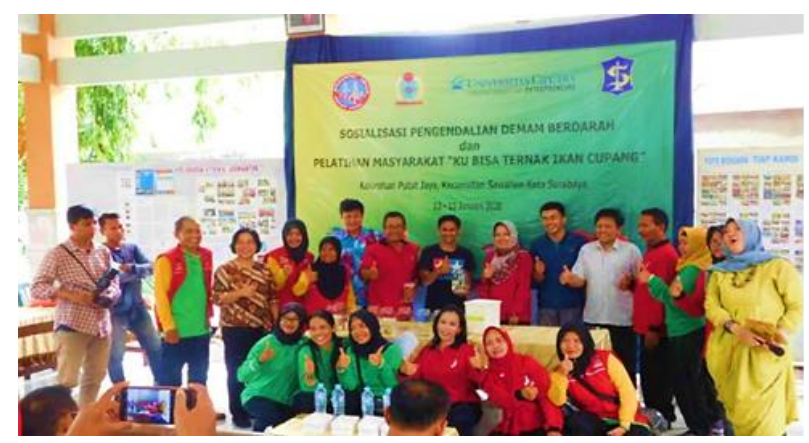

Gambar 6. Foto Bersama Kelompok Terbaik dengan Panitia Pelaksana

Seluruh peserta seperti ditunjukkan pada Gambar 7, selama dua hari berturut-turut, masih tetap menunjukkan semangat dan kegembiraan yang luar biasa setelah acara sesi terakhir yaitu sesi tanya-jawab langsung yang dipandu atau diberikan langsung oleh Narasumber.

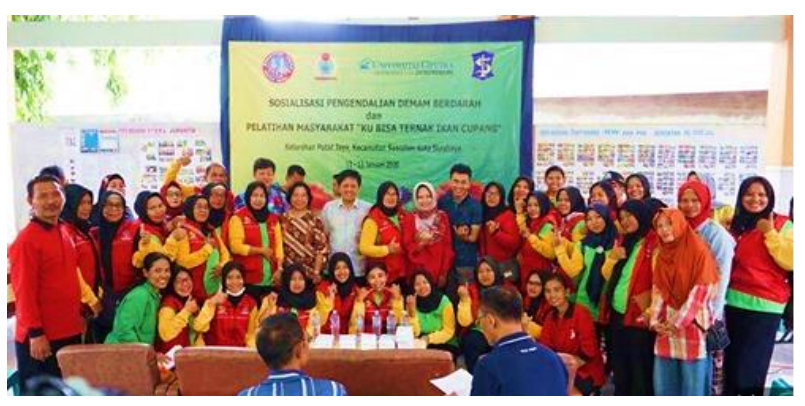

Gambar 7. Foto Bersama Seluruh Peserta dengan Tim Pelaksana

Pada sesi penutup, panitia telah memberikan kesepatan sambutan kepada Kepala Puskesmas Kelurahan Putat Jaya, Ibu dr. Ayu Ekanita H, dalam kata sambutnya telah menyampaikan bahwa kegiatan ini untuk mengingatkan kembali kepada masyarakat cara pengendalian DBD, dan juga ucapan terima kasih kepada Tim Universitas Ciputra Surabaya, atas kepeduliaannya terhadap masyarakat Kelurahan Putat Jaya, sebagaimana disajikan pada Gambar 8 .

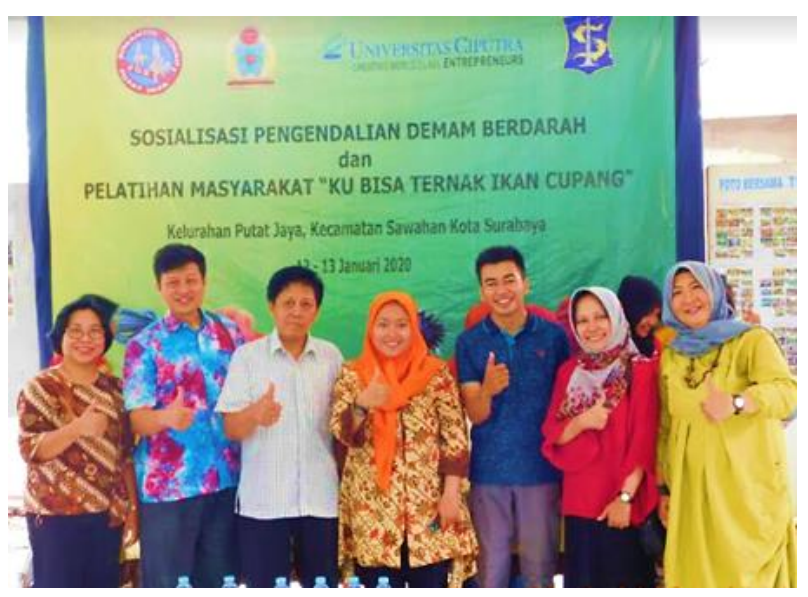

Gambar 8. Foto Bersama Seluruh Tim Pelaksana dengan Kepala Puskesmas Kelurahan Putat Jaya Ibu dr. Ayu Ekanita H

\section{KESIMPULAN}

Pemberdayaan masyarakat dapat diartikan sebagai proses yang membangun masyarakat melalui pengembangan kemampuan, perubahan perilaku, dan pengorganisasian masyarakat. Aspek pemberdayaan masyarakat ada beberapa tahapan tahapan, yaitu penyadaran, pelatihan, pengorganisasian, 
pengembangan kekuatan dan membangun sebuah dinamika. Sedangkan berdasarkan hasil evaluasi pelaksanaan kegiatan Abdimas yang telah dilakukan, dapat diambil kesimpulan bahwa peserta dapat meningkatkan pengetahuan dan sekaligus mudah untuk dipraktekan. Pertama tentang pentingnya memelihara ikan cupang dan cara mudah untuk mencegah terjangkit DBD, sehingga faktor kesehatan masyarakat menjadi lebih baik, sehingga kemungkinan terjangkitnya DBD sudah relatif kecil sekali. Data secara statistik di Dinas Keshatan Kota Surabaya 2020, diprediksi terjadi penurunan penderita penyakit DBD yang signifikan. Kedua, setelah diberikan pelatihan pengembangan wirausaha, maka diharapkan masyarakat secara individu nantinya bisa menjadi usaha rumahan dan dalam jangka pendek bisa mempunyai tambahan pendapatan bagi masyarakat. Ketiga faktor lokasi Kelurahan Putat Jaya adalah sangat strategis, dengan demikian menjadi peluang usaha bagi masyarakat Putat Jaya terutama bagi calon konsumen dari wilayah Surabaya maupun dari luar Surabaya, untuk menjangkau lokasi untuk mendapatkan ikan cupang.

\section{UCAPAN TERIMA KASIH}

Tim Pelaksana mengucapkan terima kasih kepada Kepala LPPM Universitas Ciputra Surabaya yang telah memberikan pendanaan untuk kegiatan yang diberi nama "Pemberdayaan Bagi Masyarakat Mudah dan Bisa Jadi Usaha Rumahan Melalui Pelatihan Pengembangan Wirausaha Cara Ternak Ikan Cupang Di Kelurahan Putat Jaya, Surabaya".

\section{REFERENSI}

Alamsyah, D.P., Solihat, A., Suhendi, H., Firmansyah, R., Hunaifi, N., Mukminin, A., Mauliana, P., Ary, M. 2018. Pemanfaatan ICT Untuk Pengembangan Perusahaan Kecil dan
Menengah di Look at Hijab Bandung. Jurnal ABDIMAS (Pengabdian kepada Masyarakat) UBJ. 1(1):47-56.

https://dx.doi.org/10.31599/jabdimas.v1i1.2 51

Atikasari, E., Sulistyorini, L. 2018. Pengendalian Vektor Nyamuk Aedes Aegypti Di Rumah Sakit Kota Surabaya. The Indonesian Journal of Public Health. $\quad$ 13(1):73-84. http://dx.doi.org/10.20473/ijph.v13i1.2018.7 3-84

Barisan, B., Ramadhan, M.R., Mustanir, A. 2017. Sidenreng Rappang Versus Masyarakat Ekonomi Asean. In The 2nd Journal of Government and Politics International Conference. 2:258-262. Yogyakarta: Program Pascasarjana Universitas Muhammadiyah Yogyakarta.

Hadiyati, E. 2011. Kreativitas dan Inovasi Berpengaruh Terhadap Kewirausahaan Usaha Kecil. Jurnal Manajemen dan Kewirausahaan. 13(1):8-16. https://doi.org/10.9744/jmk.13.1.8-16

Hasmidyani, D., Fatimah, S., Firmansyah, F. 2017. Developing Entrepreneurial Spirit of Young Generation through Business Plan Training. Mitra: Jurnal Pemberdayaan Masyarakat. 1(1):3247. https://doi.org/10.25170/mitra.v1i1.13

Hendri, J., Nusa, R., Prasetyowati, H. 2010. Tempat Perkembangbiakan Nyamuk Aedes spp. Di Pasar Wisata Pangandaran. Aspirator: Jurnal Penelitian Penyakit Tular Vektor (Journal of Vector Borne Diseases Studies). 2(1):23-31.

Mustanir, A., Hamid, H., Syarifuddin, R.N. 2019. Pemberdayaan Kelompok Masyarakat Desa Dalam Perencanaan Metode Partisipatif. Moderat : Jurnal Ilmiah Ilmu Pemerintahan. 5(3):227-239. http://dx.doi.org/10.25147/moderat.v5i3.26 77

Mustanir A., Rusdi, M. 2019. Participatory rural appraisal (PRA) sebagai sarana dakwah muhammadiyah pada perencanaan pembangunan di Kabupaten Sidenreng Rappang. In Prosiding Konferensi Nasional ke-8 : asosiasi program pascasarjana perguruan tinggi Muhammadiyah dan Aisiyah (APРPTMA) : "tantangan pascasarjana di era revolusi industri 4.0", Universitas Muhammadiyah Sumatera Utara (UMSU) 30 November-03 Desember 2018. 2:1-9. 
Yogyakarta: Program Pascasarjana Universitas Muhammadiyah Yogyakarta.

Nugroho, B.P. 2017. Pemberdayaan Masyarakat Eks Lokalisasi Dolly Melalui Pengembangan Wirausaha Oleh Pemerintah Kota Surabaya. Kebijakan dan Manajemen Publik. 5(2):104-114.

Oktaviari, N.S., Handoyo, P. 2017. Jaringan sosial mucikari pasca penutupan lokalisasi Dolly Surabaya. Paradigma. 5(2):1-12.

Orta, N.D., Dwi, O.W., Waluyohadi, Dwitasari, P. 2018. Pemberdayaan Bagi Masyarakat Terdampak Penutupan Lokalisasi Dolly Dengan Pelatihan Desain Dan Sablon Tas Belanja. IPTEK Journal of Proceedings Series. 2:244-248. http://dx.doi.org/10.12962/j23546026.y2018i 1.3411

Pio, R.J. 2017. Pemberdayaan Kapasitas Kewirausahaan Kelompok Usaha Kecil. Journal of Business Studies. 2(1):39-47.

Setyawati, I., Purnomo, A., Irawan, D.E., Tamyiz, M., Sutiksno, D.U. 2018. A visual trend of literature on ecopreneurship research overviewed within the last two decades. Journal of Entrepreneurship Education. 21(4):1-7.

Wahyudin, U. 2012. Pelatihan Kewirausahaan Berlatar Ekokultural Untuk Pemberdayaan Masyarakat Miskin Pedesaan. Mimbar : Jurnal Sosial dan Pembangunan. 28(1):55-64. https:/ / doi.org/10.29313/mimbar.v28i1.339 